\title{
An Exploration of Company's Internal Social Media on Social Constructs and Organizational Values
}

\author{
Mei-Hsiang Wang*, Tarng-Yao Yang, Shu-Ya Hu \\ Department of Information Management, Southern Taiwan University of Science and Technology, \\ No. 1, Nan-Tai St, Yung-Kang City, Tainan County 71005, Taiwan R.O.C. \\ * Corresponding author. Tel.: +886-6-2533131 ext.4324; email: shiang@stust.edu.tw \\ Manuscript submitted February 12, 2017; accepted June 2, 2017 \\ doi: 10.17706/ijeeee.2017.7.3.212-218
}

\begin{abstract}
Social media are information-based technologies that facilitate collaboration and communication across an organization. In particular, a company's internal social media facilitate business-related communication and support its operations. However, while social media have proven to be highly beneficial to organizations, Taiwanese firms are yet to embrace such networks. Because multiple social constructs (e.g., social transactions and social capital) are executed on these networks, they can be used to create organizational values. We believe this may be a distinct finding with regard to a company's internal social media usage in work context. Thus, we conduct an exploratory study investigating how internal social media affect the social constructs and organizational values in Taiwanese firms. Two case studies are presented, based on face-to-face interviews with employees of the relevant firms. The findings suggest that social constructs are linked to creating organizational values in terms of work productivity and organizational acculturation. In addition, we confirm that a company's internal social media seem to be a strong platform for social constructs. Thus, we conclude that further empirical research is required to verify these findings.
\end{abstract}

Key words: Social media, social transaction, social capital, organizational value.

\section{Introduction}

Workplace social media have created an environment in which workers can communicate, collaborate, and share information [1], [2]. Many firms have deployed social media to facilitate informal communication and to develop social capital among employees. This also plays an important role in reinforcing an organization's culture, values, and beliefs.

Although social media help workers to connect and share information and knowledge, no existing studies have discussed the influence of social media in developing employees' social capital or in creating organizational values. While the personal use of general social media is well documented, a company's internal social media is rarely considered in a workplace setting. In particular, researchers have yet to determine what forms of social transactions are executed on internal social media, or their role in building social capital that leads to organizational values. This study focuses on how companies use internal social media to accomplish primary tasks.

With employees increasingly using social media to support collaboration, coordination, and communication, it is important to understand the value of social media at work. Most prior studies focus on which individuals use general social media, how and why they use them for social purposes, and what kinds 
of antecedents affect the usage of such media, from different perspectives, in order to determine why so many individuals invest time and energy on social media [3]-[5]. However, few studies have examined the consequences of a company's internal social media use for work-related content, particularly in the case of Taiwanese firms. In order to obtain firms' perceptions, in-depth interviews were conducted with employees. We hope our findings will be used to develop guidelines for social network management to enhance the value of companies' internal social media in practice.

\section{Literature Review}

Social media lower the transaction costs of finding and connecting with others. [6] identified seven social transactions based on a review of multiple studies (see Table 1). In this study, we refer to these categories to understand what kinds of social transactions are executed on companies' internal social media platforms.

Table 1. Social Transactions on Social Media [6]

\begin{tabular}{|c|c|c|}
\hline Category & Name & Description \\
\hline \multirow{3}{*}{$\begin{array}{l}\text { Indirect } \\
\text { Transactions }\end{array}$} & Profile design & $\begin{array}{l}\text { The profile on a SNS is the digital image of an individual on the SNS. It can best } \\
\text { describe how an individual wants to be perceived. }\end{array}$ \\
\hline & $\begin{array}{l}\text { Public displays of } \\
\text { connections }\end{array}$ & $\begin{array}{l}\text { Often friendship links seem to be used as a means to generate attention as well } \\
\text { as prestige. The relationship to and the comments of friends are often perceived } \\
\text { as the most trust worthy information on SNS profiles. }\end{array}$ \\
\hline & Friends collecting & $\begin{array}{l}\text { On certain SNSs like MySpace it is a common culture to collect as many friends } \\
\text { as possible. The number of friends indicates how socially active an individual is } \\
\text { and is hence used as a measure for popularity in certain communities. }\end{array}$ \\
\hline \multirow{4}{*}{$\begin{array}{l}\text { Direct } \\
\text { Transactions }\end{array}$} & Social searching & $\begin{array}{l}\text { Social searchers utilize SNSs to find out more about their offline network in } \\
\text { browsing the profiles and friends lists of new offline contacts. In doing so } \\
\text { context information is gathered and awareness is created that improves the } \\
\text { ability of an individual to act in this social network. }\end{array}$ \\
\hline & Social browsing & $\begin{array}{l}\text { Social browsing describes the search for individuals on a targeted basis with the } \\
\text { intention to initiate contact. Such behavior can rarely be observed in context of } \\
\text { private life, examples are the search for a romantic partner or new friends. }\end{array}$ \\
\hline & Staying in contact & $\begin{array}{l}\text { Besides social searching the dominant usage patterns of SNSs users aim at the } \\
\text { maintenance of social relationships. Users seek to recreate their offline social } \\
\text { network and stay up to date on changes in their friends' life. Individuals manage } \\
\text { their professional social network in order to maintain weak ties. }\end{array}$ \\
\hline & Social grooming & $\begin{array}{l}\text { With respect to communication the most prominent usage pattern found is the } \\
\text { facilitation of gossip and events. }\end{array}$ \\
\hline
\end{tabular}

Social media also provides ways to create relationships. Most studies accept the theoretical distinction between bonding and bridging social capital networks. Within a work context, there is a need to develop bridging relationships for access to knowledge and information dispersed across the organization. At the same time, employees must also develop bonding relationships internally in order to integrate this information and knowledge derived from external networks. Thus, both bridging and bonding networks are necessary for work.

The emergence of specialized social media targeting specific groups indicates that these networks can add value in several ways. To date, many studies have documented the personal use of general social media, but few consider a company's internal social media. [7] conducted a qualitative case study and proposed a framework for classifying companies that use social network sites (SNS) in the workplace. The study analyzed Brazilian companies for empirical evidence to support a causal relationship between the use of social media and their value to organizational processes. However, further research is required to ascertain the effective use in the specific context of a company's internal social media (see Table 2). Thus, we attempt to supplement these earlier studies, focusing on social transactions, social capital, and organizational values 
from the perspective of a firm. We focus on social capital generation or maintenance among employees using a company's internal social media. We also explore how social networks create a complex nexus between personal and professional social capital in the workplace.

Table 2. Recent Studies on Social Media at Workplace

\begin{tabular}{|c|c|c|c|c|}
\hline Source & Social Media & Key Points & Subject & Research Method \\
\hline $\begin{array}{l}\text { Yokoyama \& } \\
\text { Sekiguchi (2014) } \\
{[7]}\end{array}$ & $\begin{array}{l}. \text { Internal SNS } \\
\text { External SNS }\end{array}$ & $\begin{array}{l}\text { Organizational context } \\
\text {. Reasons for using SNS } \\
\text { Social capital } \\
\text {. Privacy and disclosure }\end{array}$ & Brazilian companies & $\begin{array}{l}\text { Qualitative data from } \\
12 \text { interviews of } 6 \\
\text { companies from } \\
\text { different industries }\end{array}$ \\
\hline Seman (2014) [8] & General SNSs & $\begin{array}{l}\text { To examine SNS usage behavior } \\
\text { and patterns among employees } \\
\text {. To identify the relationship } \\
\text { between social networking with } \\
\text { work productivity } \\
\text {. Making connections and contact, } \\
\text { sharing knowledge, learning new } \\
\text { skills, and stress relief }\end{array}$ & $\begin{array}{l}\text { A total of } 250 \\
\text { questionnaires were } \\
\text { randomly } \\
\text { distributed to three } \\
\text { different } \\
\text { organizations in } \\
\text { Malaysia }\end{array}$ & $\begin{array}{l}\text { Quantitative } \\
\text { approaches }\end{array}$ \\
\hline $\begin{array}{l}\text { Francois, } \\
\text { Hebbani, \& Rintel } \\
\text { (2013) [9] }\end{array}$ & Facebook & $\begin{array}{l}\text { To explore how faculty employees } \\
\text { at a particular university used } \\
\text { Facebook at work }\end{array}$ & $\begin{array}{l}\text { employees of a large } \\
\text { Australian university }\end{array}$ & $\begin{array}{l}\text { Quantitative } \\
\text { research: data from } \\
900 \text { employees }\end{array}$ \\
\hline $\begin{array}{l}\text { Vitak, Lampe, } \\
\text { Gray, \& Ellison } \\
(2012)[10] \\
\end{array}$ & Facebook & $\begin{array}{l}\text { Strategies for managing context } \\
\text { collapse }\end{array}$ & $\begin{array}{l}\text { Staff personnel at a } \\
\text { large U.S. university }\end{array}$ & $\begin{array}{l}\text { Qualitative data from } \\
26 \text { interviews of } \\
\text { university staff }\end{array}$ \\
\hline $\begin{array}{l}\text { Fryling \& Trubitt } \\
\text { (2012) [11] }\end{array}$ & Wiki & $\begin{array}{l}\text { Attitudes towards the value of } \\
\text { communication/collaboration } \\
\text {. The use of social networking } \\
\text { technologies in the workplace }\end{array}$ & $\begin{array}{l}\text { a public research } \\
\text { university in US }\end{array}$ & Case study \\
\hline $\begin{array}{l}\text { Lindbom \&Wu } \\
(2010)[12]\end{array}$ & General SNSs & $\begin{array}{l}\text { User Experience of SNSs } \\
\text {. Personal Perception of Life and } \\
\text { Work } \\
\text {. Professional Experience } \\
\text { The Future of SNSs } \\
\text {. Negative opinions about SNSs }\end{array}$ & $\begin{array}{l}\text { Consulting firms in } \\
\text { Sweden }\end{array}$ & $\begin{array}{l}\text { Data be collected } \\
\text { through } \\
\text { observations, } \\
\text { interviews, media, } \\
\text { and many other } \\
\text { sources } \\
.10 \text { participants } \\
\text { were interviewed } \\
\text { from the consulting } \\
\text { industry }\end{array}$ \\
\hline $\begin{array}{l}\text { Turner, Qvarfordt, } \\
\text { Biehl, } \\
\text { Golovchinsky, \& } \\
\text { Back (2010) [13] }\end{array}$ & $\begin{array}{l}\text { communication } \\
\text { tools - email, } \\
\text { blogs, wikis, } \\
\text { Twitter, etc. }\end{array}$ & $\begin{array}{l}\text { To characterize the current } \\
\text { communication ecologies that } \\
\text { workers assemble. } \\
\text {. Identified distinct classes of } \\
\text { users based on patterns of tool } \\
\text { use. }\end{array}$ & $\begin{array}{l}\text { in a small US } \\
\text { corporation }\end{array}$ & $\begin{array}{l}\text { Surveys :50 } \\
\text { employees and } \\
\text { contractors } \\
\text {. Interviews: } 23 \\
\text { interviews }\end{array}$ \\
\hline $\begin{array}{l}\text { Skeels \& Grudin } \\
\text { (2009) [14] }\end{array}$ & $\begin{array}{l}\text { Facebook, } \\
\text { LinkedIn }\end{array}$ & $\begin{array}{l}\text {. Attitudes } \\
\text {. Behaviors }\end{array}$ & $\begin{array}{l}\text { in a large, } \\
\text { technologically-savvy } \\
\text { organization }\end{array}$ & $\begin{array}{l}\text { A broad survey } \\
\text {. Thirty focused } \\
\text { interviews }\end{array}$ \\
\hline
\end{tabular}

\section{Method}

This is an exploratory study focusing on the development of social media networks from the perspective of social transactions and social capital using guided interviews and in-depth analysis. The relevant literature suggests that interview technique is essential in case study context. Thus, in our study, semi-structured, open-question interviews were conducted at employees by investigators and the interview 
transcript and any initial inferences drawn by the investigator were shown to the interviewee for comment/verification. Essentially, we aim to understand the adoption of social media in a work setting. The case organizations are service companies and we interviewed the manager and staff of the two Taiwanese firms (Case 1 \& Case 2). The people interviewed are the company's senior employees with a good understand of the business and its use of company-internal social media. During the processes of interview, we focused on specific policy for using company-internal social media, social transactions on company-internal social media, social capital, and organization value, which are based upon a number of past studies to understand and examine some specific facets of company-internal social media employees' experience, and its implications for firms.

We employed content analysis to define constructs and measures of interest, collected and analyzed data to draw inferences. Participants' answers were initially coded and analyzed based on social media functions and social constructs and organization values. This gives us the possibility to recognize specific factors in a specific context. We used the following open-ended questions:

- What is your opinion on the use and restriction of company-internal social media in the workplace?

- How can an employee leverage the power of company-internal social media in the work context?

- How do employees make use of company-internal social media to communicate within the workplace?

- What kind of social transactions are executed on company-internal social media and why?

- Can social transactions influence the development of social capital?

- Can social capital promote organizational value?

- What are the benefits associated with using a company-internal social media platform?

In keeping with the case study design, multiple sources of evidence are gathered to converge upon the research question. The findings are summarized and discuss in the next section.

\section{Results}

We adopt a qualitative approach for a deeper understanding of why decisions on social media use are taken, and how they are implemented. The interviews probed employees' understanding, use, and history of the company's internal social media. The interview is divided into three sections to describe how social media are adopted.

\subsection{Capability of a Company's Internal Social Media}

A company's internal social media, which facilitates business-related connections, are used as a supporting platform for organizational operation. For example, employees must always sign in into internal social media before starting work. In this way, organizations announce news, share relevant information with employees, and track ongoing tasks through various functions of the platform (data management, on-line learning, workflow tracking, performance evaluation and customer service).

\subsection{Social Constructs}

Social media provide several ways to create new and maintain existing relationships. Social media enable employees to share and create useful knowledge. Employees utilize a company's internal social media to build relationships at the workplace. Through the platform, employees create social transactions and build connections with coworkers. In addition, Case 1 encourages employees to use the internal social media for learning. Here, it is necessary to access information dispersed across the organization in a work context. Through social media, employees develop the linkages necessary to enhance their knowledge and improve their work efficiency.

\subsection{Organizational Values}


The modern workplace is inherently collaborative, and this collaboration relies on effective communication among coworkers. Social networks benefit a company in terms of better communication and information availability. Using a company's internal social media, employees can quickly find information and save time when resolving problems. That is, a company's internal social media enhances the communication and collaboration between employees, further facilitating workplace productivity. A company's internal social media are a worthwhile resource for activities that require information and understanding.

Based on the above, we deduce that a company's internal social media are a valuable platform for social constructs and organizational values. Figure 1 indicates the influence of internal social media on social constructs and organizational values.



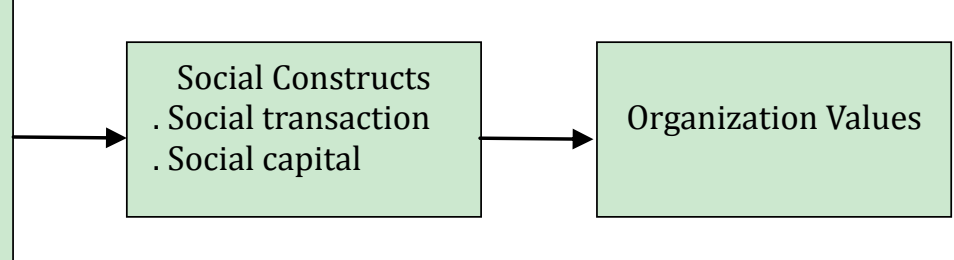

Fig. 1 The findings based on case studies.

\section{Conclusion}

Social media platforms have the potential to become a valuable resource, supporting communication and collaboration among coworkers. Our findings indicate that a company's internal social media play an important role in employees implementing social transactions and creating social capital. The employees in the case study organizations learn about their colleagues' lives and use this information in social interactions that directly and indirectly support job-related tasks. These results are consistent with those of [7]. Internal social media are used to exchange knowledge and increase visibility. Increased online discussions via social media can generate social capital and organizational benefits. This is why organizations need to use social media to enable employees to connect with each other and participate in discussions and meetings [15].

To obtain the full benefits of social media in social networking contexts, it is imperative that we determine best practices for companies' internal social media before implementing a social network environment. In Taiwan, we know many firms use internal social media, but we do not know enough about how such activities benefit the organization or the individuals. The contribution of this study centers on the following main themes: current communication practices in the workplace, how employees adopt social media, and the value of a company's internal social media to Taiwanese firms.

Relevant findings may provide initial evidence that social media can potentially play an important role in helping connections and developing relationships among employees in practice, which will further lead to developing organizational values. Therefore, this study provides a starting point to examine the use of internal social media in Taiwanese firms. Our findings can help managers set expectations and directions for social media in enterprises, as well as guide the design of such platforms.

\section{Limitations and Future Research}

Our study is subject to a number of limitations. First, the study focused on only two company-internal social media from two organizations. We suggest future research with a broader converge in different enterprise contexts to better understanding of organization usage of social media on social capital and 
business values. Second, we found the links among the capabilities of company-internal social media, social constructs and organization values. Future research can be conducted to confirm the proposed model with large samples to validate the links or add the relevant factors for testing. Finally, other theories or different perspectives may be applied to explain the adopted of company-internal social media in various contexts. To sum up, it is important to create a suitable social media environment between employees in order to improve organization values.

\section{Acknowledgment}

This manuscript is supported by the research fund MOST 104-2410-H218-018- granted by the Ministry of Science and Technology, Taiwan R.O.C.

\section{References}

[1] Dabbagh, N., \& Kitsantas, A. (2012). Personal learning environments, social media, and self-regulated learning: A natural formula for connecting formal and informal learning. The Internet and Higher Education, 15(1), 3-8.

[2] Lang, W. (2005). Knowledge spillovers in different dimensions of proximity. Regional Growth Agendas. Regional Studies Association International, Aalborg.

[3] Mondi, M., Woods, P., \& Rafi, A. (2008). A uses and gratification expectancy model to predict students' perceived e-learning experience. Educational Technology \& Society, 11(2), 241-261.

[4] Diddi, A., \& LaRose, R. (2006). Getting hooked on news: uses and gratifications and the formation of news habits among college students in an internet environment. Journal of Broadcasting \& Electronic Media, 50(2), 193-210.

[5] Ko, H., Cho, C. H., \& Roberts, M. S. (2005). Internet uses and gratifications: A structural equation model of interactive advertising. Journal of Advertising, 34(2), 57-70.

[6] Richter, D., Riemer, K., \& vom Brocke, J. (2010). Social transactions on social network sites: Can transaction cost theory contribute to a better understanding of internet social networking? BLED2010 Proceedings. 39.

[7] Yokoyama, M. H., \& Sekiguchi, T. (2014). The use of social network sites in the workplace: A case study in Brazilian companies. Brazilian Business Review, 11(2), 87.

[8] Seman, S. A. A. (2014). Organizational member use of social networking sites and work productivity. International Journal of Innovation, Management and Technology, 5(1), 30-34.

[9] Francois, A., Hebbani, A., \& Rintel, S. (2013). Facebook in the university workplace. Media International Australia, 149(1), 15-27.

[10] Lampe, C., Vitak, J., Gray, R., \& Ellison, N. (2012). Perceptions of facebook's value as an information source. Proceedings of the SIGCHI Conference on Human Factors in Computing Systems (pp. 3195-3204).

[11] Fryling, M., \& Trubitt, L. (2012). Information technology (IT) professional perceptions regarding the value of communication, collaboration, and the use of social networking technologies in the workplace: A case study. Proceedings of the Conference on Information Systems Applied Research (p. 1508).

[12] Lindbom, A, \& Wu, I. C. (2010). Employees, perceived benefits of social networking sites in the workplace. Jönköping International Business School Master Thesis within Business Administration (JMFD28). Sweden.

[13] Turner, T., Qvarfordt, P., Biehl, J. T., Golovchinsky, G., \& Back, M. (2010). Exploring the workplace communication ecology. Proceedings of the SIGCHI Conference on Human Factors in Computing Systems (pp. 841-850).

[14] Skeels, M. M., \& Grudin, J. (2009). When social networks cross boundaries: A case study of workplace 
use of facebook and linkedin. Proceedings of the ACM 2009 International Conference on Supporting Group Work (pp. 95-104).

[15] Ferrer, E., Bousoño, C., Jorge, J., Lora1, L., Miranda1, E., \& Natalizio1, N. (2013). Enriching social capital and improving organizational performance in the age of social networking. International Journal of Information, Business and Management, 5(2), 94-109.

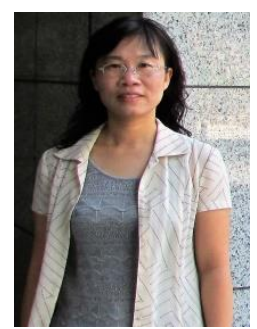

Mei-Hsiang Wang is an associate professor of information management, Southern Taiwan University of Science and Technology, Taiwan. Her research interests revolve managerial aspects of ISD project team and knowledge management in software development. Her work has been published in journals such as Journal of e-Business, Journal of Information Management, NTU Management Review, International Journal of Organization Innovation, Advances in Management and Applied Economics and others.

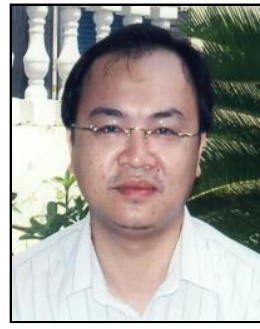

Tarng-Yao Yang is an associate professor of information management, Southern Taiwan University of Science and Technology, Taiwan. His research focuses on decision modeling, related topics of digital opportunity center and knowledge management in project team. He has published his work in journals such as Journal of e-Business, Journal of Information Management, NTU Management Review, Journal of Technology and others.



Shu-Ya Hu is a master student of information management, Southern Taiwan University of Science and Technology, Taiwan. Her research interests are social media, social capital, and organizational performance. 